\title{
Beware, cardiovascular surgeons! Dangerous plaque has been sighted in your operative field
}

\author{
John W. Hammon, MD
}

\author{
From the Department of Cardiothoracic Surgery, Wake Forest University School of Medicine, Winston-Salem, \\ NC. \\ Disclosures: Author has nothing to disclose with regard to commercial support. \\ Received for publication Oct 6, 2017; accepted for publication Oct 7, 2017 \\ Address for reprints: John W. Hammon, MD, Department of Cardiothoracic Surgery, Wake Forest University \\ School of Medicine, Medical Center Blvd, Winston-Salem, NC 27157 (E-mail: jhammon@wfubmc.edu). \\ J Thorac Cardiovasc Surg 2018;155:518-9 \\ $0022-5223 / \$ 36.00$ \\ Copyright (c) 2017 by The American Association for Thoracic Surgery \\ https://doi.org/10.1016/j.jtcvs.2017.10.003
}

Andersen and colleagues, ${ }^{1}$ the authors of the article in this issue of the Journal, "Atheromatous Disease of the Aorta and Perioperative Stroke," are a mixed group of cardiovascular specialists who address the issue of aortic atherosclerosis and how this process complicates surgical intervention. They have provided a bibliography that reviews pathogenesis, spontaneous rupture with atheroembolism, and dissection. This section is very good and should be read by all those clinicians, medical or surgical, who plan to treat aortic disease. It is obvious that this complicated disease process dramatically affects surgical and catheterbased intervention most often with rupture, plaque fracture, and distal embolism and dissection both primary and iatrogenic at the time of intervention.

The bibliography includes several references from 5 to 10 years ago that were concerned with protecting the brain during the thousands of coronary bypass cases which were in their heyday at that time. Because most of those cases were not significantly complicated, brain injury could be managed fairly easily. In the current era, many elderly and ill patients are undergoing coronary artery bypass grafting surgery and catheter intervention, with a greater chance of stroke or cognitive damage as well as embolism to other sites. The authors of this article give little support to the current trend toward off-pump revascularization to avoid surgical trauma to ascending aorta plaques. Several recent publications support so-called no-touch technique, and multiple sequential internal thoracic artery anastomoses to avoid clamping or otherwise damaging ascending plaques. 2,3 These techniques have lowered the stroke rate from $1.5 \%$ to $0.6 \%$. Because elderly patients often have very small thoracic arteries, another technique involves no-touch harvesting of the greater saphenous veins and the use of multiple sequential vein-coronary anastomoses, with good results. ${ }^{4,5}$ The most current publication from Emory Medical Center and affiliated hospitals reports achievement of similar results, but with an important warning. Many surgeons who practice off-pump revascularization use one of several "clampless facilitating devices"

\section{References} Surg. 2018;155:508-16. Surg. 2011;141:1116-27.

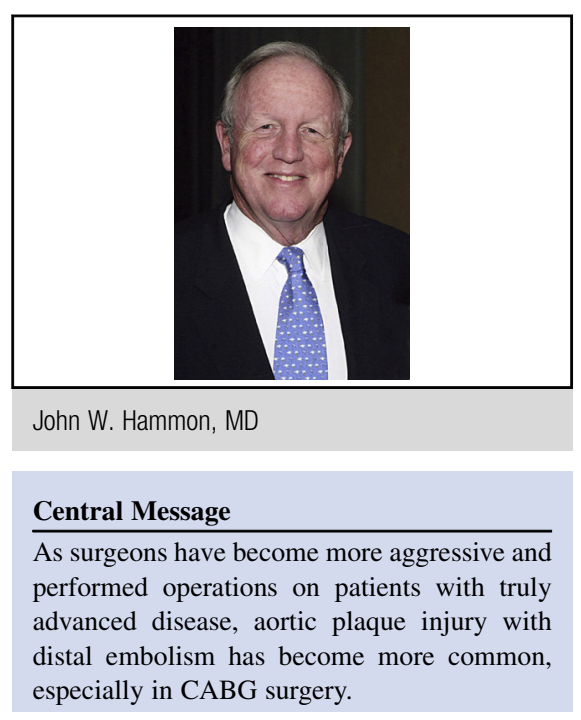

See Article page 508

to perform graft-aortic anastomoses with no crossclamp. The Emory group measured potential emboli by using transcranial Doppler ultrasound. Single clampless facilitating device use was associated with a very low transcranial Doppler ultrasound embolus count, whereas multiple clampless facilitating device use was associated with a significantly higher count. The reasons for this increase are probably related to small pieces of aortic tissue released during the cutting portion of the procedure. ${ }^{6}$

As time marches on, the surgical care of patients with aortic atherosclerosis and severe coronary disease or aortic stenosis is improving, allowing surgeons to offer a safe and atraumatic intervention. Analysis of data such as these should still be performed in a randomized fashion, because blinding is not possible.

1. Andersen ND, Hart SA, Devendra GP, Kim ES, Johnston DR, Schroder JN, et al. Atheromatous disease of the aorta and perioperative stroke. J Thorac Cardiovasc

2. Puskas JD, Stringer A, Hwang SN, Hatfield B, Smith AS, Kilgo PD, et al. Neurocognitive and neuroanatomic changes after off-pump verses on-pump coronary bypass grafting: long-term follow-up of a randomized trial. J Thorac Cardiovasc

3. Moss E, Puskas JD, Thourani VH, Kilgo P, Chen EP, Leshnower BG, et al. Avoiding aortic clamping during coronary artery bypass grafting reduces postoperative stroke. J Thorac Cardiovasc Surg. 2015;149:175-80.

4. Souza DS, Johansson B, Bojö L, Karlsson R, Geijer H, Filbey D, et al. Harvesting the saphenous vein with surrounding tissue for $\mathrm{CABG}$ provides long-term graft patency comparable to the left internal thoracic artery: results of a randomized longitudinal trial. J Thorac Cardiovasc Surg. 2006;132:373-8. 
5. Samano N, Geijer H, Liden M, Fremes S, Bodin L, Souza D. The no-touch saphenous vein for coronary artery bypass grafting maintains a patency, after 16 years, comparable to the left internal thoracic artery: a randomized trial. J Thorac Cardiovasc Surg. 2015;150:880-8.
6. Halkos ME, Anderson A, Binongo JNG, Stringer A, Lasanajak Y, Thourani VH et al. Operative strategies to reduce cerebral embolic events during on- and off pump coronary artery bypass surgery: a stratified, prospective randomized trial. J Thorac Cardiovasc Surg. 2017;154:1278-85.e1. 